\title{
Deficit in static grain storage capacity in the state of Goiás in the 2016/17 harvest
}

\author{
André Felippe Monteiro Guimaraes ${ }^{1}$, Mariana Pina da Silva Berti ${ }^{1}$, Natalia Arruda , \\ Christian Luis Ferreira Berti ${ }^{1}$ \\ ${ }^{1}$ Universidade Estadual de Goiás, Campus Sudeste, Unidade Universitária de Ipameri, Ipameri, Goiás, Brasil. E-mail: \\ mariana.berti@ueg.br, andrefelippemg@gmail.com,nathy.a@hotmail.com,christianberti@unirv.edu.br
}

Received: 18/10/2018; Accepted: 01/02/2019.

\begin{abstract}
The Central-West region has been highlighted as the largest agricultural center in the country, accounting for $42 \%$ of national grain production. Goiás State represented an amount of 18.9 million tons in the last harvest. Despite the large production, a problem which affects the negotiations and the quality of the harvested grains is storage. A static capacity of $20 \%$ higher than grain production is recommended. The objective of this work was to evaluate the storage capacity of grains in the State of Goiás and their respective mesoregions using a comparison with the agricultural production of the Center-West region. The deficit in the static storage capacity of grain in Goiás for the $2016 / 17$ harvest was $25.17 \%$ in relation to grain production, since the recommended amount for safe storage is $20 \%$ higher than production, which indicates the need for a $45.17 \%$ increase in the State's static storage capacity to supply the demand for products throughout the year and to support the producers so that they can be competitive in the domestic and international markets in the commodity negotiations. Public policies to support the creation and expansion of storage are necessary, since the investment made in the structures is high and the return of spending is not immediate.
\end{abstract}

Keywords: Storage; Agricultural crops; Goiás; Mesoregions; Logistics.

\section{Déficit na capacidade estática de armazenagem de grãos no estado de Goiás na safra 2016/17}

\section{RESUMO}

A região Centro-Oeste vem se destacando como o maior polo agrícola do país, sendo responsável por $42 \%$ da produção nacional de grãos. O Estado de Goiás representou um montante de 18,9 milhões de toneladas na última safra. Apesar da grande produção, um problema que afeta as negociações e a qualidade dos grãos colhidos é o armazenamento. Recomenda-se uma capacidade estática $20 \%$ superior à produção de grãos. O objetivo deste trabalho foi avaliar a capacidade de armazenamento de grãos no Estado de Goiás e suas respectivas mesorregiões, utilizando um comparativo com a produção agrícola da região Centro-Oeste. O déficit na capacidade estática de armazenamento de grãos em Goiás para a safra de 2016/17 foi de 25,17\% em relação à produção de grãos, visto que o recomendado para uma armazenagem segura é $20 \%$ superior à produção, o que indica a necessidade de um acréscimo de 45,17\% na capacidade estática de armazenamento do Estado para suprir a demanda por produtos durante todo o ano e respaldar os produtores, para que possam ser competitivos no mercado nacional e internacional nas negociações de commodities. Políticas públicas de apoio à criação e ampliação dos armazéns são necessárias, visto que o investimento realizado nas estruturas é alto e o retorno dos gastos não é imediato.

Palavras-chave: Estocagem; Culturas agrícolas; Mesorregiões; Logística. 
Brazil stands out on the world stage as one of the largest producers and exporters of grains, supplying countries with great demand for products, among them China and the United States. The Brazilian production of commodities has surpassed records with each harvest. Technological development, favorable climatic factors and dedication of producers and professionals linked to agribusiness place Brazil among the most competitive countries in world agriculture.

According to CONAB (2017), grain production in Brazil for the 2016/2017 harvest reached 238.7 million tons, a total corresponding to an increase of $24.3 \%$ in relation to the 2015/2016 harvest. Soy and corn play a fundamental role in increasing Brazilian productivity, being responsible for $90 \%$ of the grains produced, and despite the high production, the planted area has not undergone much change, thus revealing the excellent technological situation present in the country.

In conjunction with the increase in grain production in Brazil and the possibility of having multiple harvests in the same year, the demand for adequate infrastructure and logistics have grown. Logistics has undergone major changes in recent years, since its activities have only focused on domestic supply and emergencies in the local market, however with the growing global socioeconomic change, there have been evolutionary transformations with the aim of expanding its areas of operation. Brazil also fits into the problems related to storage and logistics; with the increase in the grain volume in the harvests, the physical structure does not parallel the production evolution. Storage and disposal of grains are correlated with the production and commercialization of the final product intended for the consumer, being a sequence of factors in which each part must have equal relevance (Aleixo and Silva, 2015).

Storage is one of the most important and ancient activities of mankind, and when properly carried out its primary focus is to preserve the quality of the food, thereby avoiding losses and enabling greater competitiveness in the market, especially in the offseason. Forming inventories favors chronological distribution and supply from granaries located at strategic points in logistics, preventing frequent changes in prices (Giovine and Christ, 2010).

According to CONAB (2017), grain storage capacity in Brazil remains insufficient. There are currently 17.7 thousand granaries registered with a capacity to store 157.6 million tons of grain; however, the production estimate for the 2016/17 harvest exceeded 230 million tons, which results in a deficit impact on the static capacity in Brazil.

In the current decade, the Midwest has become the main agricultural hub in the country. According to CONAB, the region represented $42 \%$ of national grain production, reaching a surprising 88 million tons in the agricultural cycle. The State of Goiás is the second largest producer in the country, after only Mato Grosso, and reached a record harvest corresponding to 18.9 million tons of grain in an area of 5.1 million hectares (CONAB, 2017).

According to Aleixo and Silva (2015), Goiás has a high deficit in static storage capacity, and if all production needs to be stored, the capacity should be expanded by approximately $44.83 \%$ so that it is possible to meet all local demand.

In view of the above, the objective of this work is to evaluate the grain storage capacity in the State of Goiás and its respective mesoregions using a comparison with agricultural production in the Midwest region.

The exploratory research methodology was applied based on data from the National Registry of Storage Units System (SICARM) and on surveys of harvests from the National Supply Company (CONAB).

The research was developed from bibliographic reviews on grain storage in the State of Goiás and the current condition of static capacity in the 2016/2017 harvest. The data used is freely accessible and are available on the website www.conab.gov.br.

The information regarding the static storage capacity and the grain production were condensed by mesoregions of the State of Goiás. The tables and figures were then constructed to carry out the necessary analyzes. Data from the 2016/2017 harvest and the State's static capacity, which is made available by CONAB, were used to calculate the storage deficit in the State of Goiás.

Finally, the current situation of the location of the granaries and the type of storage unit: Storage Unit at farm level; Collector Storage Unit; Intermediate Storage Unit; and Terminal Storage Unit were described according to the predominance in each region (Aleixo and Silva, 2015).

Table 1 shows the evolution of agricultural production combined with the static capacity of the state of Goiás.

\section{Static capacities of the mesoregions in the state of Goiás}

The State of Goiás is divided into five agricultural mesoregions: North, Northwest, East, Center and South. According to the IMB - Instituto Mauro Borges of Statistics and Socioeconomic Studies (2014a), Goiás occupies the $4^{\text {th }}$ position in the national ranking of agricultural production, and its main mesoregions which collaborate for this important position are the South and East. The south of Goiás is responsible for approximately $75 \%$ of the State's production, since this region corresponds to some of the main grain producing municipalities in Brazil such as Rio Verde and Jataí. The development of static capacity in some regions of Goiás is associated with the productive history and the expansion of the agricultural scenario in the area. 
Despite the high grain production, the storage capacity is still below what is necessary. According to Aleixo and Silva (2015), the ideal capacity would be $20 \%$ higher than grain production, and the State of Goiás has a storage deficit of $4,439.04$ million tons, which represents a deficit of $25.17 \%$ in the storage capacity, thus hindering better competitiveness in the agricultural export scenario and showing unpreparedness to meet a possible record harvest. Figure 1 shows the respective mesoregions of the State of Goiás with their static grain storage capacities (SICARM, 2017).

\section{Storage capacities according to their location}

According to Aleixo and Silva (2015), the grain storage units are divided into five different models: farmlevel storage unit, in which the agricultural company is located next to rural properties and only serving the producer; collecting storage unit, which are mediumsized granaries, serving more than one producer, located in a strategic position to facilitate farmers' logistics; subterminal storage unit, located in a strategic position to receive production from several farmers together with the grains of the collecting units; terminal storage unit, which is close to major consumption centers, ports and strategic locations, aiming to facilitate exports, reducing transportation costs. Grain storage in Goiás has collector type storage units as its main characteristic, which are mainly represented by granaries and silo batteries. Figure 2 shows the number of granaries available throughout the State and their respective characteristics.

\section{Number of storage units and static capacity by storage type}

According to Aleixo and Silva (2015), grain storage can be carried out in two ways: a) bulk, when the grains are disposed without packaging in silos, which can be masonry, metal or concrete; and b) conventional granaries, when the grains are stored in bags and kept in warehouses or sheds which have favorable temperature and humidity characteristics for storage. In the State of Goiás, bulk granaries in the form of metallic silos predominate, as agricultural expansion provides greater investment in storage units.

Table 2 presents the data on the static capacity of conventional granaries and bulk carriers in the respective mesoregions of the state of Goiás. Note that the South region has the largest number of storage units, both for conventional granaries and bulk carriers. In Figure 3, the grain production by mesoregion and its respective static capacity is represented, with the South of Goiás standing out as the largest grain producing and storage region.

\section{Transport logistics}

Four modes of transport are used to transport grain in Brazil: water, land, air and pipeline. The most used modal in the State of Goiás is by road, with an increase in the costs of agricultural production; however, investments in infrastructure and an increase in the railway network could collaborate with the flow of agricultural production in the State (Rodrigues, 2004).

An increase in the road network has been noted during the last decades, however this has not been verified for the waterway and railway modes; this fact can be observed by the difference in the current size between these two modes in the State of Goiás: 27.9 thousand kilometers of highways (IMB, 2014b) and 685 kilometers of railways (Rodriguez, 2011). Waterway and railroad networks are almost nil in the state of Goiás when compared to roadways.

According to the Goiás Secretariat of Management and Planning SEGPLAN (2011), the road network in Goiás is responsible for most of the cargo displacement and passengers. There are 24,994 km of highways in the State, of which $52.7 \%$ are paved, $3.9 \%$ are unpaved and $13.4 \%$ are in planning or paving works.

The main federal highways of the State are BR-153, which connects the north to the south of the country, BR060 connecting Goiânia to Brasília, and BR-050 which connects the Federal District to the south of Brazil.

The importance of the main highways in the State is evidenced by the production flow, not only to Goiás, but throughout the country. BR-060 stands out for cutting the South-Goiana region due to the vast grain production, forming a strategic logistic corridor for the grain flow from all over the country.

There is a link between a large part of the state's mesoregions with the BR-153, which is of great importance, cutting practically every state and connecting with the North-South railroad.

According to Silva Neto et al. (2016), the NorthSouth railroad will reduce fuel costs, transportation costs, high expenses with highway maintenance and also the number of accidents in the locations. A section of the railway is concluded in Goiás, which changed the logistics profile of the regions including the railway modal, making the State more competitive in the respective negotiations of its agricultural production.

Regarding transport modes, another important factor to be considered is the use of waterways, which are a more economically viable mode of transport with the possibility of being explored in the State of Goiás.

According to Silva Neto et al. (2016), investments in other forms of transport are being implemented, such as the Multimodal Logistics Platform and Porto Seco Central-West in the city of Anápolis, which constitute investments of extreme importance and have better expectations about the improvements in logistics in Goiás. Figure 4 presents the logistics of Goiás with a presentation of the respective transport modes currently used in the region. 
The deficit in static grain storage capacity in Goiás for the 2016/17 harvest was $25.17 \%$, which indicates the need for a $45.17 \%$ increase in the state's static storage capacity to supply the demand for products during the year. Public policies to support the creation and expansion of granaries are necessary, since the investment made in the structures is high and the return on expenses is not immediate.

Table 1. Grain production and storage in the State of Goiás.

\begin{tabular}{ccc}
\hline Year & $\begin{array}{c}\text { Grain production } \\
\text { (millions/ton) }\end{array}$ & Static capacity of granaries (millions/ton) \\
\hline 2006 & 10755.00 & 12433.70 \\
2007 & 11235.30 & 12435.70 \\
2008 & 12829.70 & 12970.80 \\
2009 & 13030.60 & 12964.45 \\
2010 & 13347.80 & 12955.70 \\
2011 & 15446.80 & 11916.80 \\
2012 & 18187.90 & 12890.20 \\
2013 & 17656.50 & 13161.03 \\
2014 & 18679.80 & 12613.10 \\
2015 & 19620.52 & 11999.70 \\
2016 & 17635.40 & 13196.36 \\
\hline
\end{tabular}

Source: Adapted from CONAB (2017).

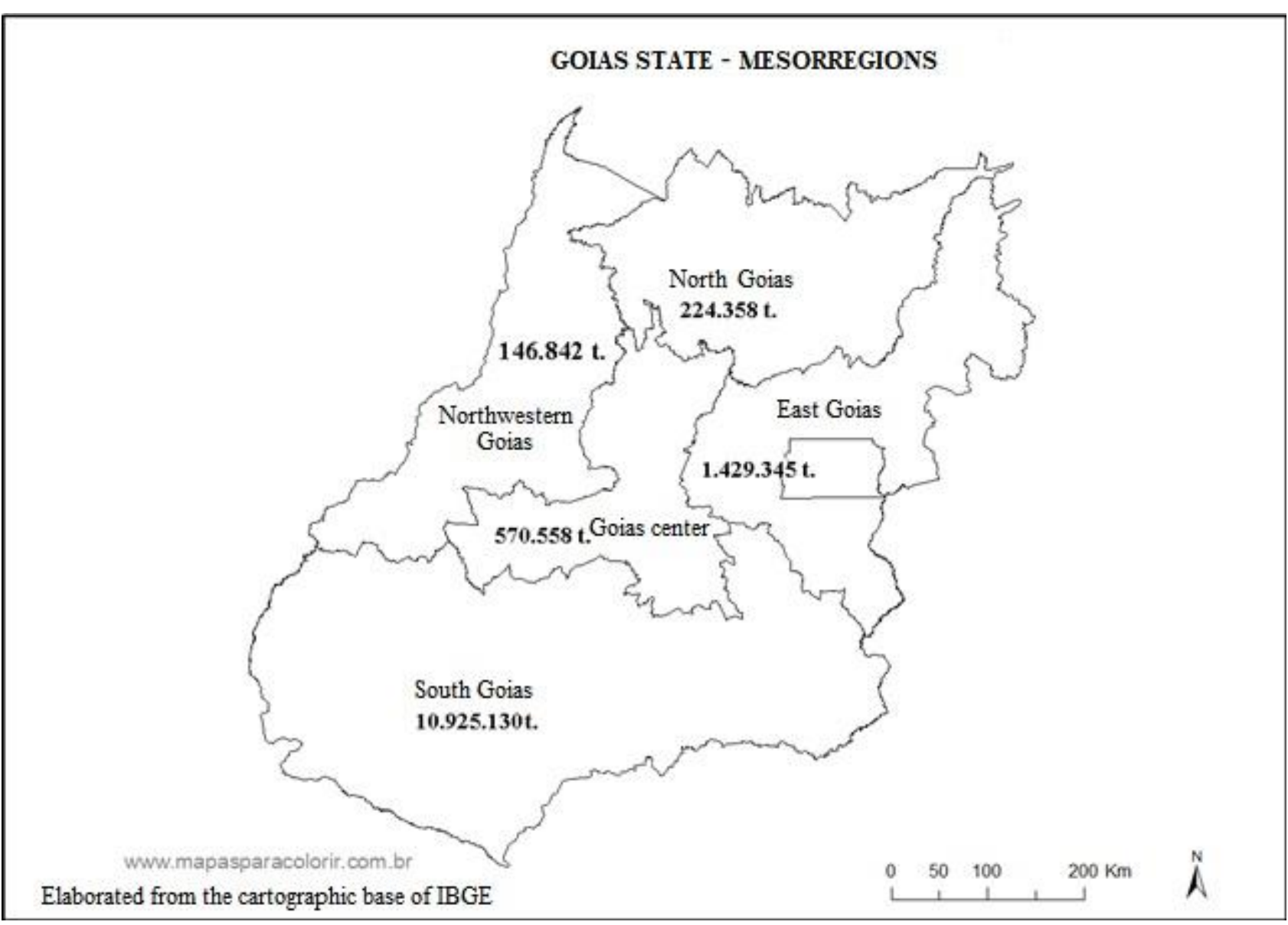

Figure 1. Distribution of the static storage capacity of the State of Goiás by mesoregions.

Source: Prepared by the author from the IBGE cartographic base, with data from SICARM (2017). 


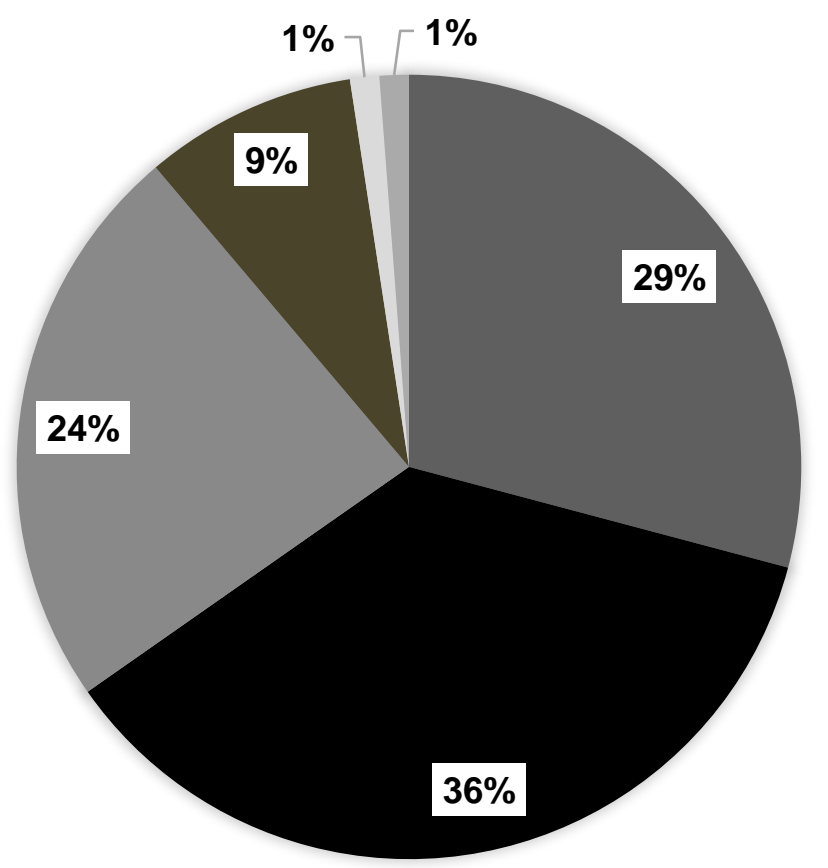

nulk carriers

- Battery of silos

- Conventional

- Silo

Deposit

Chinese hat

Figure 2. Types of grain storage units in Goiás.

Source: Prepared by the author based on data obtained from CONAB (2017).

Table 2. Static capacity of conventional granaries and bulk carriers in the respective mesoregions of the state of Goiás.

\begin{tabular}{ccccc}
\hline \multirow{2}{*}{ Region/Granary } & \multicolumn{3}{c}{ Conventional } & \multicolumn{2}{c}{ Bulk carriers } \\
\cline { 2 - 5 } & Number & Capacity (t) & 29 & Capacity (t) \\
\hline Central & 16 & 65.940 & 143 & 504.618 \\
East & 76 & 213.684 & 6 & 1.215 .661 \\
Northwest & 5 & 22.192 & 19 & 124.650 \\
North & 7 & 18.616 & 501 & 205.742 \\
South & 111 & 523.549 & 698 & 10.442 .281 \\
\hline Total & 215 & 843.981 & 12.492 .952
\end{tabular}

Source: Adapted from SICARM (2017).

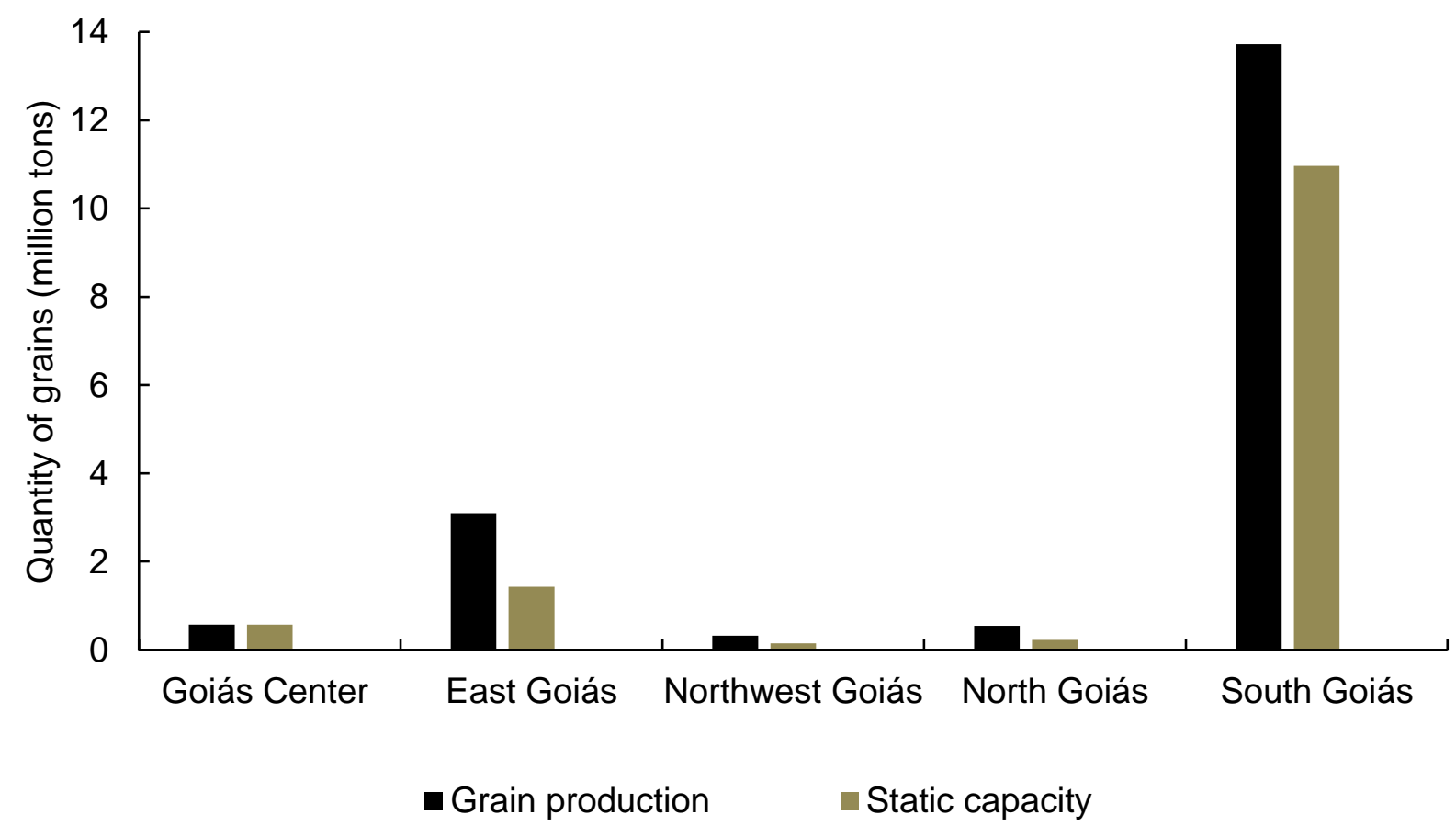

Figure 3. Grain production and static storage capacity (in millions of tons).

Source: Prepared by the author based on data obtained from CONAB (2017). 


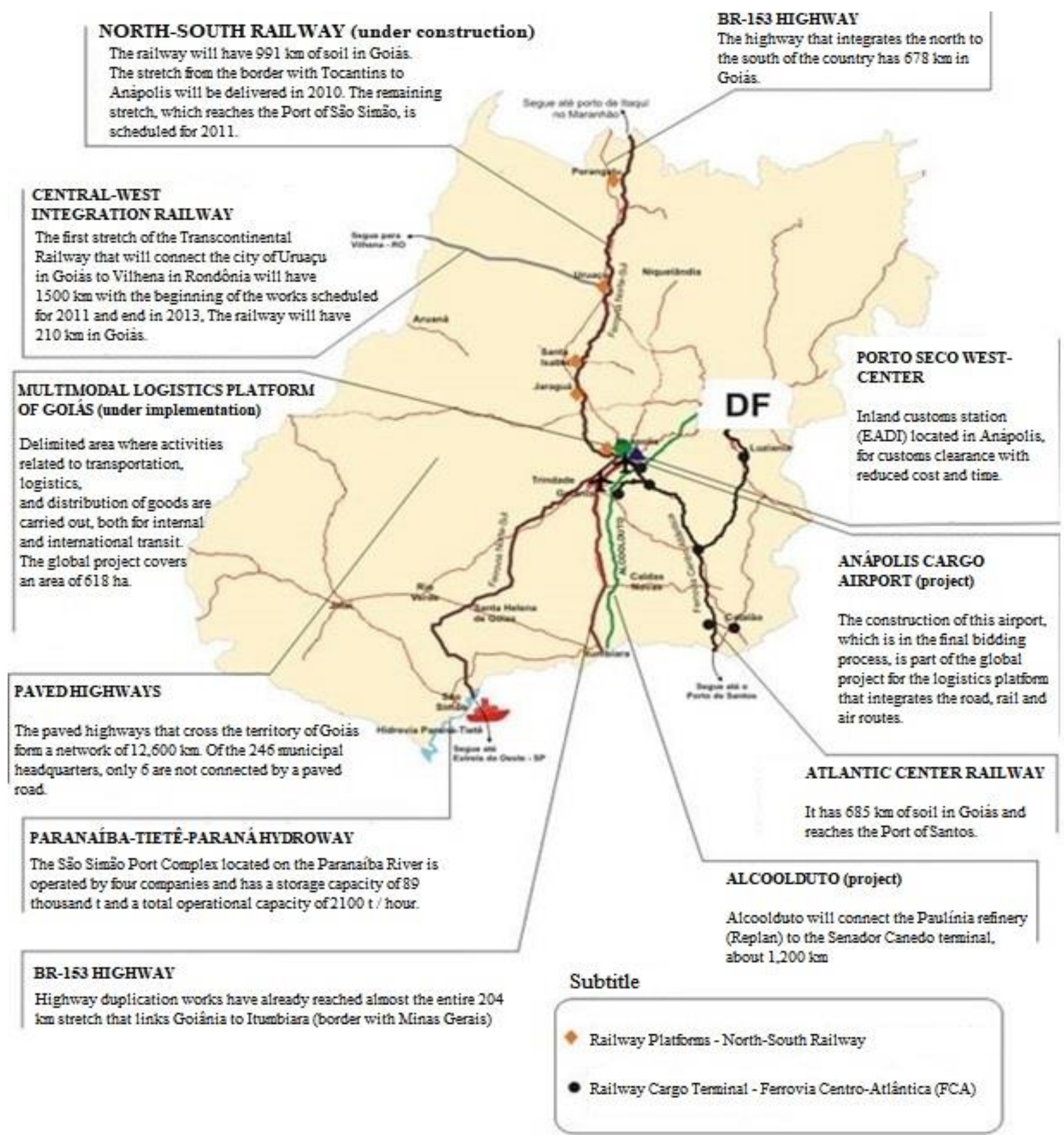

Figure 4. Transport logistics in the State of Goiás.

Source: IMB (2014b).

\section{Bibliographic References}

Aleixo, N.C., Silva, A.M.M., 2015. Análise da capacidade estática de armazenagem de grãos no estado de Goiás. http://www.unirv.edu.br/conteudos/fckfiles/files/NATHALIA $\% 20-\% 20$ ANALISE\%

20DA\%

20CAPACIDADE\%20ESTATICA\%20DE\%20ARMAZENA GEM\%20DE\%20GRAOS\%20NO\%20ESTADO\%20DE\%20 GOIAS.pdf (Acessado 13 de julho de 2017).

CONAB. Companhia Nacional de Abastecimento, 2017. Armazenagem. Brasília. http://www.conab.gov.br/OlalaCMS/uploads/arquivos/17_08_ 10_11_27_12_boletim_graos_agosto_2017.pdf (Acessado 03 de agosto de 2017).
Giovine, H., Christ, D., 2010. Estudo sobre processos de armazenagem de grãos - um estudo de caso - região de Francisco Beltrão - PR. Ciências Sociais Aplicadas em Revista, 10(18), 139-152.

IMB. Instituto Mauro Borges, 2014a. Estatísticas das meso e microrregiões do Estado de Goiás: 2014. Segplan: Goiânia.

IMB. Instituto Mauro Borges, 2014b. Goiás em Dados. http://www.seplan.go.gov.br/sepin/Fviewnot.asp?id_cad=1209 \&id_not=5\#transporte (Acessado 24 de julho de 2017).

Rodrigues, P.R.A., 2004. Introdução aos Sistemas de Transporte no Brasil e à Logística Internacional, terceira ed. São Paulo, Edições Aduaneiras Ltda. 
Rodriguez, S.H., 2011. A importância da estrada de ferro para o estado de Goiás. Revista UFG, 13(11), 69-74.

SEGPLAN. Secretaria de Estado de Gestão e Planejamento, 2011. Governo do Estado de Goiás. Goiás e dados. http:// www.seplan.go.gov.br/sepin/down/godados2011.pdf (Acessado 05 de agosto de 2017).
SICARM. Sistema Nacional de Cadastro de Unidades Armazenadoras, $2017 . \quad$ Brasília. http://consultaweb.conab.gov.br/consultas/consultaArmazem.d o?method=acaoCarregarConsulta (Acessado 05 de agosto de 2017).

Silva Neto, W.A., Arruda, P.N., Bastos, A.C., 2016. O déficit na capacidade estática de armazenagem de grãos no estado de Goiás. Gestão \& Regionalidade, 32(96), 151-169. 